\title{
MENDES, Pedro Rosa. Peregrinação de Enmanuel Jhesus. Lisboa: Dom Quixote, 2010. 352p.
}

\author{
Mário Rufino \\ Universidade Nova de Lisboa
}

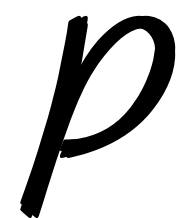

eregrinação de Enmanuel Jhesus contém uma fulgurante riqueza imagética, complexidade narrativa e demanda existencial sobre a génese de uma cultura.É um dos grandes livros da literatura contemporânea, assumidamente influenciado pela literatura de viagens desde o século XVI até à actualidade.

O território do romance (fiquemos por esta caracterização embora a hibridez do texto permita catalogá-lo de outras formas) não se limita à geografia de um território. É uma viagem pelos momentos históricos que moldaram as características do povo de Timor Lorosae. A viagem do autor pela psicologia, cultura e sociedade timorense, com todas as suas interacções e indefinições culturais, sustenta-se não só numa deslocação física, essencial à literatura de viagens, mas também numa viagem na literatura. Se no primeiro caso, como foi dito, o observador desloca-se de um ponto a outro, no segundo caso tal não é necessário. Em Peregrinação de Enmanuel Jhesus, o autor interroga de forma endógena e exógena a génese de uma sociedade e a formação cultural do indivíduo. O pensamento e as interrogações levantadas pelo autor, em muitos casos, funcionam com alguma independência, mas não dissociados, 
em relação à deslocação física do observador. A existência de constantes viagens entre o passado e o presente demonstra-nos as múltiplas influências existentes/impostas a Timor Lorosae

Eu posso recordar, na minha memória genética de judeu, que o nosso povo operou essa passagem, essa mudança, porque ela nos foi imposta do exterior. A primeira vez foi quando tivemos de passar a lei oral em lei escrita, na Primeira Diáspora, quando os Judeus foram expulsos pelos Assírios e sofremos o exílio da Babilónia. ${ }^{1}$

Pedro Rosa Mendes dotou o seu romance com uma complexidade narrativa que obriga o leitor a ler e reler e, mesmo assim, sair do livro com a sensação que ficou por apreender grande parte da riqueza existente.

Não é a primeira vez que um livro do mesmo autor causa um impacto tão forte como a sua Peregrinação. "A baía dos tigres" interroga, também, as convenções literárias ou o que se chama de construção e leitura canónica. A hibridez de ambos os livros é uma característica em comum, entre outras. Mas mais do que haver uma ligação entres estes dois livros, a Peregrinação desenhada por Pedro Rosa Mendes remete de forma intrínseca e extrínseca para outra viagem, para outra peregrinação: a de Fernão Mendes Pinto.

As duas obras não se conformam com a representação da realidade, mas almejam capturá-la nas malhas da ficção. Acontece um deslizamento da interpretação factual para a leitura ficcional na obra de Pedro Rosa Mendes embora não tão ostensivo como na obra de Fernão Mendes Pinto. Há uma constante dialéctica entre a ficção e a realidade. $\mathrm{O}$ deslocamento do viajante leva-o ao descobrimento de realidades diferentes daquela que ele conhece e onde é participante activo. $\mathrm{O}$ "Outro"

${ }^{1}$ MENDES, 2010, p.284. 
aparece, então, aos seus olhos significando estranheza e deslocamento do "eu" para uma realidade até ali desconhecida. Quando o seu olhar incide sobre o "Outro" a alteridade efectuase. No entanto, é uma posição efémera pois o viajante tenta, imediatamente, apoderar-se dela não só a nível linguístico como social.

O que se pensa é ver como é que se pode integrar um certo número de coisas a que os Timorenses estão habituados. Um tipo de expressão, de linguagem, de rituais. Vemos como se pode encontrar um paralelismo ou integração de valores para que as pessoas possam exprimir, de uma forma entendível para elas, a realidade mistérica do Cristianismo. ${ }^{2}$

A analogia com os costumes que conhece é inevitável e o que é novo é comparado com a imagética existente. Há uma íntima relação entre a tessitura histórica e social e a narração.

A estranheza demonstrada perante o "Outro", já não sendo geográfica, ainda se mantém como psicológica, cultural e linguística.

Em Peregrinação de Enmanuel Jhesus, Que-Deus-Tem, timorense, recorda:

(...) não foi a dor. Foi a confusão e raiva diante de uma Gramática da Língua Portuguesa que não abarcava a conjugação da realidade dos meus sujeitos. Debaixo das reguadas, pensei inventar um dia uma Gramática da Língua Timorense que conjugue a verdade timor sem erro, sem medo de reguadas,

«uma!»

onde o sujeito possibilite uma pessoa primeira do plural e o verbo exista no pretérito do indicativo "Três!!!"3

${ }^{2}$ MENDES, 2010, p. 34

${ }^{3}$ MENDES, 2010, p.160. 
$\mathrm{O}$ indivíduo, quando assimila uma língua, habita um universo de planeamento intelectual, evolução diacrónica de uma cultura, onde é agente activo, e onde interage com o objectivo de a perpetuar. Não era, obviamente, a condição de Que-Deus-Tem. No exemplo de Que-Deus-Tem, a separação entre a cultura, que contém a imagética de um povo, e a língua resultou, na perspectiva do educador, num erro punível. A impossibilidade de transferência de um conceito de tempo, de uma ideia de ordem/sintaxe, para a língua oficial é criadora de uma imagem de incapacidade intelectual de quem não consegue adaptar-se a essa língua. Se pensarmos que uma pessoa, como agente social, estabelece relações com um vasto conjunto de grupos sociais que, através da interacção, definem a sua identidade, então conseguimos perceber a profundidade do problema.

O espírito do povo, a alma e a memória da nação têm a sua expressão primordial e autêntica na língua nacional, sendo de certo modo defectivo um sentimento nacional que não se exprima numa língua própria. ${ }^{4}$

Se em vários aspectos o viajante admira-se e conta de forma não-interventiva os costumes da nova realidade, tudo se altera quando escolhe a religião como hermenêutica. Quando adopta tal ângulo para uma indevida medição, o observado é adjectivado de forma pejorativa em comparação com os hábitos do observador. Perde-se a isenção e institui-se um patamar de inferioridade/superioridade. Em "A Peregrinação de Fernão Mendes Pinto", basicamente narrado na primeira pessoa, isto acontece de forma ostensiva; na Peregrinação de Enmanuel Jhesus acontece de forma diferente e, talvez, mais complexa.

${ }^{4}$ SILVA, 2004, p. 27- 28 
Ao assumir uma narração polifónica, a narrativa enriquece-se com a pluralidade de pontos de vista com possível fragmentação da evolução do romance. Devido, essencialmente, à mestria com que o autor domina a construção do texto, a narrativa não perde coerência.

A leitura crítica da Peregrinaçam percorre 4 séculos onde podemos acompanhar a história da poética e caracterização da literatura de viagens como marginal ao cânone.

Pedro Rosa Mendes assume esta herança e oferece-nos um livro soberbo, que exige leitura e releitura. Peregrinação de Enmanuel Jhesus é um acontecimento literário que merece perdurar no tempo e deixar a sua marca na História da Literatura Portuguesa.

\section{Referências bibliográficas}

LABORINHO, Ana Paula Martins. O rosto de Jano - Universos ficcionais da Peregrinaçam de Fernão Mendes Pinto". $1^{\circ}$ volume, Lisboa. Tese (Doutorado) - Universidade de Lisboa, Faculdade de Letras, 2006.

LIMA, Francisco Ferreira de. O outro livro das maravilhas: alteridade e diferença na Peregrinação de Fernão Mendes Pinto. Tese (Doutorado) - Universidade de São Paulo, Faculdade de Filosofia, Letras e Ciências Humanas, 1996.

MARQUES, Maria Emília Ricardo. Sociolinguística. Lisboa: Universidade Aberta, 1995.

MENDES, Pedro Rosa. Peregrinação de Enmanuel Jhesus. Lisboa: Dom Quixote, 2010.

PINTO, Fernão Mendes. Peregrinação. $1^{\circ}$ volume. Lisboa: Europa América, 1996.

PINTO, Fernão Mendes. Peregrinação. $2^{\circ}$ volume. Lisboa: Europa América, 1997. 
SEIXO, Maria Alzira; ZURBACH, Christine. O discurso literário da Peregrinação - aproximações. Lisboa: Edições Cosmos, 1999.

SILVA, Vítor Manuel Aguiar e. Contributos para uma política da Língua Portuguesa. In: A Lingua Portuguesa: Presente e Futuro. Lisboa: Fundação Calouste Gulbenkian, 2004. 25-36

SIMÕES, Manuel. A Literatura de viagens nos séculos XVI e XVII. Lisboa: Editorial Comunicação, 1985. 